\title{
RADIKALISME, MODERATISME, DAN LIBERALISME PESANTREN: \\ Melacak Pemikiran dan Gerakan Keagamaan Pesantren di Era Globalisasi
}

\author{
Umma Farida \\ STAIN Kudus, Jawa Tengah, Indonesia. \\ mafarahman@gmail.com
}

\begin{abstract}
Kajian ini bertujuan untuk melacak pemikiran dan gerakan keagamaan pesantren di era globalisasi. Pendekatan dalam peneltian ini adalah penelitian kepustakaan. Hasil penelitian ini adalah radikalisme dan liberalisme sebuah pesantren sangat tergantung kepada para pemimpin di pesantren tersebut (pemilik, kyai, atau santri senior). Jika arus pemikiran para pemimpinnya berkarakter radikal, maka sebuah pesantren beserta santrinya akan berpandangan radikal, sedangkan jika para pemimpinnya berkarakter moderat, maka sebuah pesantren beserta santrinya berkarakter moderat, bahkan bisa menjadi liberal dalam situasi dan waktu tertentu. Sejalan dengan globalisasi, wajah pesantren di Indonesia sudah tidak lagi dimonopoli oleh kelompok tradisional atau fundamental-radikal, melainkan sudah diwarnai oleh pesantren-pesantren baru yang di bentuk oleh kelompok Islam lainnya dengan wajah yang berbeda pula.
\end{abstract}

Kata kunci: radikalisme, moderatisme, liberalisme, pesantren, globalisasi 


\section{Abstract}

RADICALISM, MODERATISM, AND BOARDING LIBERALISM (KEEP TRACK OF THOUGHT AND BOARDING SCHOOL RELIGIOUS MOVEMENT'S IN THE GLOBALIZATION ERA). This study aims to track the movement of thought and boarding school religious movement in the globalization era. This study uses library research. The result of this study is the radicalism and liberalism of a boarding school is very dependent upon the leaders in its boarding school (owner, kyai, or senior students). If the current leaders have radical character thought, then a boarding school with its students will think the radically, whereas if its leaders are moderate, so a boarding school and its students will have moderate characteristic, even they can be liberal in a certain situation and time. In line with the globalization, the face of boarding school in Indonesia is no longer monopolized by traditional or fundamental-radical group, but it was already colored by boarding schools in new forms by other Islamic groups with different faces.

Keywords: radicalism, moderatism, liberalism, boarding school, globalization

\section{A. Pendahuluan}

Pesantren merupakan lembaga pendidikan Islam yang cukup populer, khususnya di Jawa. Pesantren secara etimologis berasal dari kata pe-santri-an yang berarti tempat santri, dan secara fungsional dapat didefinisikansebagai sebuah institusi yang memiliki fungsi pendidikan, dakwah, kemasyarakatan dan-bahkan pada masa kolonial—juga berfungsi perjuangan.

Pasca terjadinya peledakan bom di WTC dan menara pentagon di AmerikaSerikat,isu seputar radikalisme dan terorisme kembali menghiasi pemberitaan dan beberapa media, baik cetak maupun elektronik. Setelah peristiwa itu, terjadi pengeboman Hotel JW. Marriot, pengeboman di Jl. Legian Bali dan peristiwa lain yang dilakukan oleh sekelompok tertentu dengan mengusung simbolsimbol agama. Kelompok radikal ini semakin merajalela dalam melakukan aktifitas gerakannya, dengan meruntuhkan nilai-nilai kemanusiaan atas nama agama. Sayangnya, perilaku kekerasan atas nama agama ini secara simplistik dikaitkan dengan kelompok agama tertentu dan institusi pendidikan tertentu, salah satunya adalah 
pesantren. Padahal di sisi lain, seiring dengan semakin meningkatnya arus globalisasi, pesantren sebenarnya tidak hanya memiliki pemikiran dan gerakan keagamaan yang radikal saja, namun juga moderat, bahkan beraliran liberal.

\section{B. Pembahasan}

\section{Pengertian Globalisasi}

Istilah globalisasi sering diberi arti yang berbeda antara yang satu dengan lainnya, sehingga di sini perlu penegasan lebih dulu. Globalisasi diambil dari kata'global',yang mengindikasikan bahwa dunia adalah sebuah kontinuitas lingkungan yang terkonstruksi sebagai kesatuan utuh. Marshal McLuhans sebagaimana dikutip Muhtarom (2005: 44) menyebut dunia yang diliputi kesadaran globalisasi sebagai 'desa buana' (global village). Dunia menjadi sangat transparan sehingga seolah tanpa batas administrasi suatu negara. Batas-batas geografis suatu negara menjadi kabur. Globalisasi membuat dunia menjadi transparan akibat perkembangan ilmu pengetahuan dan teknologi informasi.

Akbar S. Ahmed dan Hastings Donnan dalam Azizy (2004: 19) membatasi bahwa globalisasi 'pada prinsipnya mengacu pada perkembangan-perkembangan yang cepat di dalam teknologi komunikasi, transformasi, informasi yang bisa membawa bagianbagian dunia yang jauh menjadi hal-hal yang bisa dijangkau dengan mudah.' Sebagai contoh, kasus buku Satanic Verses tulisan Salman Rushdie di akhir tahun 1980-an. Hanya dalam waktu ukuran jam, apa yang terjadi di Inggris, dengan mudah sudah ada respons di Pakistan dan India. Protes meledak di mana-mana. Begitu cepatnya berita tentang buku tersebut merebak ke seluruh penjuru dunia, sebagai perwujudan era komunikasi,transformasi dan informasi.

Selain itu, globalisasi juga merupakan istilah yang digunakan untuk menggambarkan proses multilapis dan multidimensi dalam realitas kehidupan yang sebagian besar dikonstruksi oleh Barat. Karenanya, tidak dapat dipungkiri jika dengan globalisasi juga terjadi pertemuan dan gesekan nilai-nilai budaya dan agama di seluruh dunia. Pertemuan dan gesekan ini akan menghasilkan kompetisi liar yang berarti saling dipengaruhi (dicaplok) dan mempengaruhi (mencaplok); saling bertentangan dan bertabrakan nilai-nilai yang 
berbeda yang akan menghasilkan kalah atau menang; atau saling bekerjasama (eclectic) yang akan menghasilkan sintesa dan antitesa baru (Azizy, 2004: 20).

Istilah 'globalisasi' ini juga dapat diartikan sebagai alat dan juga sebagai ideologi. Diartikan sebagai alat dikarenakan ia merupakan wujud keberhasilan ilmu-teknologi, terutama sekali di bidang komunikasi. Ketika globalisasi berarti alat, maka globalisasi sangat netral. Artinya, ia berarti dan sekaligus mengandung hal-hal positif, ketika dimanfaatkan untuk tujuan yang baik. Sebaliknya, ia dapat berakibat negatif jika digunakan dalam hal-hal negatif, sehingga globalisasi akan tergantung kepada siapa yang menggunakannya dan untuk keperluan dan tujuan apa dipergunakan. Jadi, sebagai alat dapat bermanfaat dan dapat pula membawa mudarat. Terobosan teknologi informasi dapat dijadikan alat untuk dakwah; dan dalam waktu bersamaan dapat pula menjadi 'biang kerok' ancaman dakwah.

Adapun globalisasi sebagai ideologi, telah memiliki arti tersendiri dan netralitasnya sangat berkurang. Oleh karena itu, tidak aneh kalau kemudian tidak sedikit yang menolaknya. Sebab, tidak sedikit akan terjadi benturan nilai, antara nilai yang dianggap sebagai ideologi globalisasi dan nilai agama, termasuk agama Islam.

\section{Respon Pesantren terhadap Globalisasi}

Globalisasi merupakan suatu era global dimana dunia terasa seperti sebuah kampung kecil. Interaksi antar negara, peradaban dan budaya semakin mudah dilakukan. Proses salingmempengaruhiantar satubudayadenganbudaya yang lain semakin intens dan dengan proses yang cepat, baik budaya itu bersifat positif atau pun negatif. Sehingga pada akhirnya globalisasi menjadi alat untuk saling mempengaruhi antar peradaban, budaya, ideologi bahkan agama.

Proses saling mempengaruhi tersebut menjadikan suatu peradaban, budaya dan agama terkontaminasi dengan unsur- unsur yanglain.Hal ini menimbulkan kegoncangan bagi ideologi dan budaya lain yang tidak sesuai karakteristik sosial kulturalnya, termasuk juga dialami oleh lembaga pendidikan Islam seperti pesantren.

Secara umum, paradigma yang berkembang di kalangan umat Islam dalam menghadapi globalisasi adalah: 
Pertama, paradigma konservatif. Paradigma ini cenderung memposisikan Pesantren sebagai lembaga penagama yang memiliki doktrin dan ikatan-ikatan tradisi lama yang belum mau bersentuhan dengan wacana keilmuan selain Islam. unsur-unsur sosial selain Islam dalam hal ini dianggap sebagai bagian yang senantiasa berlawanan bahkan mengancam. Paradigma seperti ini didasarkan pada perspektif holistik, yang memposisikan hubungan antara agama Islam dan persoalan kemasyarakatan sebagai sesuatu yang tak terpisahkan. Menurut mereka, Islam bukanlah semata-mata agama dalam pengertian Barat, yakni hanya menyangkut hubungan antara manusia dan Tuhan, melainkan Islam adalah agama yang sempurna dan lengkap yang mengatur segala aspek kehidupan manusia, sehingga doktrin dan ikatan-ikatan tradisi lama yang ada tidak dapat bersentuhan dengan wacana keilmuan selain Islam, termasuk menganggap bahwa globalisasi adalah unsur yang sangat mengancam bagi keberlangsungan nilai-nilai Islam.

Kedua, paradigma liberal. Pesantren yang mengusung paradigma ini mengasumsikan bahwa Islam adalah agama yang dapat berperan sebagai agen perubahan sosial. unsur- unsur sosial selain Islam dalam hal ini menjadi komponen yang diterima bahkan menjadi acuan penting di dalam merumuskan berbagai solusi terhadap persoalan kekinian yang dihadapi umat. Dalam dimensi teologi paradigma ini mengedepankan aspek rasionalisme. Teologi bukan semata menjadi objek kajian bagaimana meyakinkan umat secara doktriner, melainkan sebagai pembimbing tindakan praksis sosial. Selain itu, teologi juga harus lepas dari paradigma kekuasaan negara, bahkan harus menjadi bagian transformasi sosial yang terus menyuarakan kepentingan mayoritas umat. Paradigma ini berpendirian bahwa walaupun Islam memiliki doktrin dan ikatanikatan tradisi lama tapi harus dilakukan banyak dekonstruksi terhadap pemahaman doktrin tersebut. Berkebalikan dengan teologi kaum konservatif yang gigih membela Tuhan, dimensi teologi yang mereka ajukan justru menginginkan konsistensi menjelmakan nilai tauhid sebagai ajaran yang membebaskan umat dari penindasan kultural dan struktural. Mereka lebih menekankan pembelaan terhadap nilai-nilai kemanusiaan,sehingga terkadang melampaui garis-garis "larangan" demi mewujudkan teologis humanisnya. Dalam dimensi syariat 
paradigma ini mengambil hukum-hukum melalui pemahaman yang cenderung terlalu kontekstual, sehingga terkadang mengabaikan tekstualitas dan latar belakang munculnya doktrin-doktrin agama. Mereka juga mengajukan berbagai wacana tentang perlunya tafsir ulang terhadap al-Qur'an dan hadis.

Ketiga, paradigma moderat. Pesantren yang mengusung paradigma ini mencoba mengkompromikan dua paradigma di atas, yang cenderung mencoba mengintegrasikan pandangan-pandangan yang antagonistik dalam melihat hubungan Islam dan persoalan kemasyarakatan, sekaligus ingin melunakkan Paradigma Konservatif yang seringkali melakukan generalisasi bahwa Islam selalu mempunyai kaitan atau hubungan yang tak terpisahkan dengan masalah-masalah kemasyarakatan. Serta berusaha mengakomodasi dilakukannya pembaruan wacana sesuai dengan diinginkan kalangan liberal dengan tetap memperhatikan nilai-nilai luhur dan keislaman.

Sesuai dengan konsep Islam sebagai agama wasathan (moderat), maka dalam melihat hubungan Islam dan negara, paradigma moderat menolak pendapat bahwa Islam adalah agama yang serba lengkap dan bahwa dalam Islam terdapat sistem ketatanegaraan. Tetapi kelompok ini juga menolak anggapan bahwa agama adalah dalam pengertian barat yang hanya mengatur hubungan manusia dengan Tuhan. Paradigma ini juga berpendirian bahwa dalam Islam tidak terdapat sistem ketatanegaraan tetapi terdapat seperangkat tata nilai etika bagi kehidupan bernegara.

Pesantren yang berpegang pada paradigma ini tidak hanya ingin menonjolkan isu seputar konsep "Negara Islam" dan "Pemberlakuan syariat", tetapi yang paling penting bagaimana substansi dari nilai dan ajaran agama itu sendiri. Agama adalah sejumlah ajaran moral dan etika sosial, selain itu agama juga berfungsi sebagai alat kontrol negara. Paradigma moderat berpandangan, keterlibatan agama secara praktis ke dalam negara jangan sampai memandulkan nilai luhur yang terkandung dalam agama karena agama akan menjadi ajang politisasi dan kontestasi. Di sisi lain, paradigma ismam moderat mengkampanyekan dimensi yang sifatnya lentur, santun, dan beradab. Hal ini penting guna meminimalisir pandangan keagamaan yang selalu berwajah sangar dan keras yang digunakan secara sistematis oleh beberapa kalangan muslim. 


\section{Radikalisme Pesantren}

Pesantren yang bersikap konservatif dalam menghadapi globalisasi pada umumnya bermuara pada fundamentalisme dan radikalisme (Muin, 2007: 20). Globalisasi dipandang sebagai upaya menundukkan semua negara untuk mengikuti super power yakni Amerika. Sehingga, globalisasi disebut juga dengan Amerikanisasi, atau ekspansi universal gagasan dan nilai-nilai Amerika. Karenanya, globalisasi dapat menjadi ancaman kaburnya nilai-nilai Islam. Sejatinya, wajah radikalisme pesantren tidak pernah nyata dalam dinamika pesantren sejak abad ke-15 yang dipelopori Walisongo dan dilanjutkan oleh generasi selanjutnya melalui ulama-ulama ternama, seperti Syekh Mutamakkin, Syekh Nawawi al-Bantani, Syekh Mahfud al-Tarmasi, KH. Hasyim Asyari, KH. Wahab Hasbullah, dan masih banyak lagi. Namun, sejak zaman reformasi ini wajah radikalisme pesantren muncul ke permukaan secara nyata. Pertama, Pondok Pesantren al-Islam, Lamongan terlibat dalam aksi pengeboman Bali yang dilakukan para alumni santrinya, seperti Muchlas dan Amrozi. Kedua, Pondok Pesantren al-Mukmin, Ngruki, Sukoharjo yang dicerminkan ustadz Abu Bakar Ba'asyir sebagai tokoh utama, yang diduga ikut terlibat dalam beberapa aksi kekerasan di tanah air.

Berdasar penelitian Endang Turmudi dan Riza Sihbudi (2005: 135-137), wajah radikal kedua pondok pesantren tersebut sebenarnya lebih banyak dilakukan dalam bentuk wacana dan gerakan. Dalam bentuk wacana, dilakukan dengan memberikan materi pengajaran yang berhaluan radikal; seperti penerapan syariat Islam secara kaffah dalam kehidupan individu, masyarakat, dan negara. Mereka berkeyakinan bahwa penerapan syariat Islam akan menyelesaikan persoalan bangsa, masyarakat, dan individu. Namun mereka sejatinya tidak membenarkan cara-cara kekerasan dalam menerapkan syariat Islam tersebut. Proses penerapan syariat Islam dalam pesantren ini adalah melalui jalur pendidikan. Karena, pendidikan dipandang sebagai instrumen dalam sosialisasi penerapan nilai-nilai syariat Islam kepada santri pada khususnya dan masyarakat pada umumnya.

Dengan demikian dapat dipahami bahwa setidaknya ada dua hal yang menyebabkan proses radikalisasi di pesantren. Pertama, jaringan intelektual yang dilakukan pesantren modern 
berasal dari kawasan Timur Tengah yang berwatak keras, militan dan radikal, terutama ajaran Wahabi yang dibawa secara literal ke wilayah Nusantara. Purifikasi adalah produk nyata dari jaringan intelektual Wahabisme dalam bentuk pemberantasan takhayul, bid'ah, dan khurafat. Dalam proses selanjutnya, jaringanin telektual ini meluas, tidak saja berpatokan pada mazhab Wahabisme, tetapi juga mengambil ideologi radikal sejumlah intelektual; seperti Hasan al-Bana, Al-Maududi, Sayyid Qutb, Hasan Turabi, dan lainlain. Itu sebabnya, psikologi radikalisme yang bergolak di Timur Tengah benar-benar dipraktikkan di tanah air sebagai perjuangan luhur agama.

Kedua, pengajaran agama yang ekslusif dan dogmatik telah melahirkan sikap permusuhan dengan kelompok di luarnya. Istilah Zionis-Kafir seakan menjelma menjadi kesadaran keagamaan untuk melawannya dalam bentuk apapun. Ditambah lagi dengan ideologi jihad yang dipahami sebagai perang melawan kaum Zionis-Kafir, telah menambah deretan sikap radikal. Sehingga aksi kekerasan apapun yang dilakukan umat untuk menghancurkan Zionis-Kafir, yang mereka sebut sebagai musuh-musuh Islam, adalah perjuangan agama yang paling luhur (syahid). Pada dasarnya, pengajaran seperti ini tidak murni sebagai kesadaran otentik masyarakat Islam Nusantara, melainkan pengaruh dari jaringan intelektual dan ideologis yang dibawa dari Timur Tengah (Zada, 2002: 92-95).

Fenomena fundamentalisme dan radikalisme ini, jika dicermati, memang bukan semata-mata disebabkan oleh pola pendidikan pesantren saja atau kian sadarnya masyarakat dan meningkatnya pemahaman keagamaan mereka melainkan juga dirangsang oleh realitas yang mengelilingi kehidupan mereka dimana negara dianggap telah gagal mewujudkan kesejahteraan dan keadilan dengan sistem sekuler yang dianutnya. Fakta seperti inilah yang menjadi salah satu faktor pendorong mencari alternatif lain dalam membangun prinsip dan ideologi pembangunan yang diharapkan lebih menjamin terwujudnya kehidupan yang sejahtera dan berkeadilan.

\section{Moderatisme Pesantren}

Pesantren sebagai bagian institusi pendidikan Islam membuka diri untuk menerima sisi positif dari globalisasi, khususnya 
hal-hal yang tidak mengalami benturan dengan budaya lokal atau nasional,terutama nilai agama. Misalnya, budaya disiplin di Barat, kebersihan, tanggung jawab, egalitarianisme, kompetisi, kerja keras, penghargaan terhadap orang lain, demokratisasi dan sebagainya. Institusi ini membuka diri untuk mengadopsi sistem pembelajaran mutakhir melalui penambahan pelajaran, khususnya yang berkaitan dengan ilmu-ilmu pengetahuan non-agama. Para kiai sebagai pemimpin pesantren bersikap lapang dalam menerima perubahan bagi penyelenggaraan pembelajaran di pesantrennya, meskipun mereka juga tetap menjaga ciri khas dari sistem pendidikan Islam tradisional ini. Mereka yakin bahwa perubahan harus dilakukan sebagai respon terhadap tuntutan zaman tanpa merusak aspekaspek positif dari kehidupan masyarakat. Keterbukaan tersebut dalam kenyataannya bahkan telah semakin memperkuat keberadaan lembaga pendidikan pesantren ini (Turmudi \& Sihbudi, 2005: 131).

Pesantren yang bersikap moderat inilah yang sebenarnya merupakan karakter otentik pesantren. Sejak masa awal berdirinya, pesantren selalu menampilkan wajahnya yang toleran dan damai. Di pelosok-pelosok pedesaan Jawa, banyak ditemukan performance pesantren yang berhasil melakukan dialog dengan budaya masyarakat setempat. Pesantren-pesantren yang ada di Jawa, terutama yang bermazhab Syaf'i biasanya menampilkan sikap akomodasi yang seimbang dengan budaya setempat. Sehingga pesantren mengalami pembauran dengan masyarakar secara baik. Keberhasilan pesantren seperti ini kemudian menjadi model keberagamaan yang toleran di kalangan umat Islam pada umumnya. Tak heran, jika karakter Islam di Indonesia seringkali dipersepsikan sebagai muslim yang ramah dan damai.

Keramahan wajah pesantren dibentuk oleh karakter pesantren itu sendiri, yaitu: 1) Tawassuth yang berarti tidak memihak atau moderasi. 2) Tawazun, menjaga keseimbangan dan harmoni. 3) Tasamuh, toleransi. 4) Tasyawur, musyawarah. 5) Adil, bersikap adil dalam beraksi ataupun bereaksi.

Kelima karakter inilah yang membentuk santri dalam menjalani kehidupan riil di masyarakat. Dengan lima karakter seperti disebutkan di atas, pesantren sebagai institusi pendidikan yang mengajarkan kearifan, sangat berperan dalam meluruskan 
pemahaman tentang ajaran Islam yang secara otomatis dapat meluruskan kesalah pahaman masyarakat tentang istilah-istilah yang berkembang, misalnya dalam konteks ini adalah tentang jihad dan radikalisme.

Para kiai mengajar santri di pesantren dengan berbagai kitab mulai dari aqidah, akhlak, fiqh, tafsir, hadits, sejarah, dan lain sebagainya. Istilah jihad, mati syahid, musuh Islam, kafir dan lainlain bukanlah istilah yang asing bagi warga pesantren. Jikalau mau mengamalkan jihad dalam arti berperang misalnya, tentulah para kiai yang paling pertama melakukannya karena mereka relatif mendalam pengetahuan agamanya, termasuk dalil-dalil berjihad. Pada umumnya, pesantren yang bersikap moderat tidak pernah menggunakan kitabkitab berkategori ekstrem dari penulis yang tidak muktabar. Penulis yang muktabar adalah mereka yang silsilah keilmuan, mazhab dan gurunya diketahui banyak orang dan memiliki ketersambungan dengan ulama-ulama terkenal sebelum dan sesudahnya. Sekadar menyebut contoh, yaitu: 1) Pesantren Perguruan KH. Zainal Mustafa, Sukamanah, Tasikmalaya. 2) Pesantren Hidayatullah Islamiyah Kemiling Bandar Lampung. 3) Pesantren ar-Riyadh, Sebarang Ulu, Palembang. 4) Pesantren Syamsul Huda, Buleleng, Bali, dan 5) Pesantren Darul Ulum Bogor.

Bahkan, pesantren yang disebut terakhir ini memiliki lembaga yang dinamakan ICDW (Indomesian Center for Deradicalization and Wisdom) yang berdiri pada November 2009 dan memiliki empat program utama: 1) Riset dan Penerbitan. ICDW bekerja sama dengan siapapun untuk melakukan penelitian seputar gerakan radikal dan deradikalisasi, penelitian tentang keragaman dan kearifan budaya lokal di Indonesia. Hasil penelitian diterbitkan dalam bentuk cetak dan atau digital. 2) Dialog dan advokasi. ICDW melakukan dialog, diskusi, seminar ataupun wawancara, tentang deradikalisasi. ICDW membina mantan aktifis gerakan radikal demi terjadinya perubahan sikap keberagamaan dari radikal kepada moderat, agar bisa berbaur dengan masyarakat. 3) Beasiswa. ICDW memberikan beasiswa pendidikan kepada anak-anak mantan aktifis gerakan radikal, terutama yang telah berstatus sebagai yatim/yatim-piatu, dengan tujuan agar anak-anak terebut tumbuh sebagai generasi bangsa yang saleh. 4) Dukungan pesantren. Program dukungan kepada pesantren Darul 
Ulum, yang menyelenggarakan program pendidikan Islam tingkat dasar dan menengah yang menitikberatkan pada pembentukan sikap keberagamaan yang toleran terhadap keberagamaan pemikiran dan budaya (Muin, 2007: 141-256).

\section{Pesantren dan Paradigma Liberal}

Pesantren yang ada di beberapa wilayah teritorial Indonesia secara doktrinal mengambil empat gugus pemikiran keagamaan sebagai mainstream pengajaran, yaitu aqidah, fiqih, tasawuf, dan kalam. Keempat gugusan ini sampai sekarang masih begitu mempengaruhi alur pikir umat Islam, juga dipelajari dan dijadikan menu sehari-hari para santri baik dengan metode sorogan dan bandongan/weton (Dirjosanjoto, 1999: 149). Fiqih memiliki wilayah garapan yang bernuansa dhahir (eksoterik) dan lebih bersentuhan langsung dengan masalah keummatan, tasawuf lebih bernuansa esoterik, yang menekankan pada pergulatan kemiskinan batin, dan kalam serta filsafat berorientasi pada problem wahyu dan perkaraperkara yang mengedepankan rasionalitas berpikir.

Dari keempat disiplin itu, fiqihlah yang paling dominan, dalam arti membentuk perilaku muslim dalam meretas interaksi sosial sesamanya, meskipun aqidah, tasawuf, dan kalam juga tidak bisa diabaikan begitu saja (Al-Jabiry, 1999:164). Ketiganya turut pula memberikan nuansa tersendiri dalam pergulatan fenomena keagamaan di tanah air. Ketika problem sosial-politik semakin memanas dan tidak lagi memberikan ketentraman, maka menggeluti tasawuf merupakan alternatif ritual karena dianggap mampu memberikan kedalaman spiritualitas serta berhasil mengatasi kedangkalan batin.

Namun, akhir-akhir ini terdapat fenomena lain yang menggejala dalam dunia pesantren. Terdapat dua hal yang bisa dijadikan potret cara berpikir santri yang mengembangkan keperbedaan pandangan. Pertama, secara metodologis, santri mulai sering melakukan persentuhan dengan alur pemikiran dalam kitabkitab fikih melalui pengembangan cara penyusunan pemikiran hukum itu sendiri (istinbath al-ahkam min al-adillat). Ushul fiqh menjadi salah satu kerangka dasar pengambilan metode hukum dalam mencermati problem keagamaan kontemporer. Selain itu, 
kerangka normatif ini tertuangkan dalam sebuah legal maxims (al-qawa'id al-fiqhiyyah) yang sangat menentukan hasil akhir dari proses ketetapan hukum yang diambil. Kedua, fenomena lain yang menguat adalah perhatian serius pesantren untuk menggeluti kajiankajian perbandingan mazhab dalam fikih. Tentunya, hal ini sangat berpengaruh terhadap pandangan untuk menghargai keperbedaan pemikiran dalam Islam. Penerimaan santri untuk mengkaji kitab Bidayah al-Mujtahid karya Ibnu Rusyd dinilai sebagai langkah maju dari pergeseran pemikiran fikih kaum santri. Sikap inklusif yang dikedepankan telah meruntuhkan pandangan usang tentang pesantren sebagai kumpulan komunitas yang konservatif, primordial, eksklusif, dan anti-perubahan (Effendy, 1991:67).

Pada masa-masa selanjutnya, pergeseran nuansa di pesantren terjadi. Seiring dengan menyeruaknya arus globalisasi dan modernisasi, pesantren mau tidak mau turut melakukan adaptasi (Feillard, 1995:367).

Jika dulu pesantren tidak membolehkan para santri untuk membaca koran, menonton televisi, atau mempelajari literature umum, maka sekarang hal-hal seperti bukan lagi merupakan ketabuan. Banyak pesantren yang kemudian memasukkan beberapa disiplin ilmu-ilmu baru, bahkan banyak pula yang mendirikan sekolah-sekolah umum di dalam lingkungan pesantren itu sendiri.

Persentuhan-persentuhan dengan dunia luar ini ternyata sangat berpengaruh terhadap pola pikir kaum santri terhadap doktrin agama yang selama ini dipelajari. Akhirnya, tuntutan-tuntutan baru untuk merespon tantangan modernitas haruslah

sesegera mungkin dilakukan. Melalui metode istinbath hokum yang dikuasai, pesantren mulai mengutak-atik persoalan kontemporer tanpa kehilangan spirit keislamannya, atau dengan bahasa lain tetap mengedepankan kaidah al-muhafazhah ala al qadim al-shalih wa al-akhdzu bil jadid al-ashlah (memelihara tradisi lama yang masih bernilai baik dan merajut pembaruan yang lebih baik). Bukan hanya dalam bidang hukum Islam, dalam bidang mu'amalah pun, liberalisasi pemikiran juga dilakukan.

Salah satu contoh yang menguat adalah beralihnya fenomena hubungan antar ummat beragama. Jika dulu islamisasi sangat kontras 
kaitannya dengan kristenisasi sehingga menimbulkan kecurigaan antara satu dengan yang lainnya, maka konflik epistemologis di wilayah itu mulai dikikis. Tercetuslah dasar-dasar saling pengertian antar ummat beragama melalui pemahaman dan penafsiran baru terhadap tiga bentuk ukhuwwah, yaitu ukhuwwah Islamiyyah (persaudaraan islami), ukhuwwah wathaniyyah (persaudaraan sebangsa), dan ukhuwwah basyariyyah (persaudaraan sesama manusia). Dari beberapa contoh pergeseran (pembaruan pemikiran) di pesantren ini setidaknya menjadi tolok ukur bahwa komunitas santri bisa sangat adaptif terhadap perkembangan-perkembangan baru yang datang dari luar pesantren.

Liberalisme pesantren bukan hanya dimaknai sebagai keberanian untuk mengaduk-aduk teks-teks kegamaan dengan perangkat metodologi yang memadai, melainkan juga melakukan strategi-strategi pembacaan terhadap teks agama itu sendiri agar kontinuitas untuk melakukan produksi makna baru yang relevan dengan kondisi kekinian (Surur dalam Majalah Pesantren, 2002: 2829). Apalagi ditambah dengan masuknya gagasan liberal yang dibawa dari Barat. Ideologi demokrasi, civil society, pluralisme, dan bahkan gugatan kritis terhadap Kitab Suci (al-Qur'an dan Hadits Nabi saw.) telah merambah ke wilayah pesantren, yang selama ini dianggap mewarisi tradisi keilmuan yang standard, tidak kritis, dan terkesan jumud.

Liberalisme dalam lingkungan pesantren memang membawa sisi positif tetapi ada pula sisi negatif. Ia telah mengantarkan pemikiran keislaman yang bersifat toleran, terbuka, dan berkemajuan dalam menghadapi persoalanpersoalan global seperti demokrasi, pluralisme, kesetaraan jender dan modernisasi. Tapi yang harus diamati adalah bahwa Islam liberal telah kehilangan semangat pelacakan otentifikasi Islam, yang sesungguhnya telah tersedia dalam khazanah Islam klasik.

Rumadi (2000: 21-35) mengungkapkan bahwa pesantren sebagai komunitas keilmuan ikut berinteraksi dengan paradigm liberal. Ada dua hal yang dapat dijadikan ukuran untuk melihat masuknya gagasan liberal di komunitas pesantren. Pertama, dilihat dari sudut pemikiran tokoh-tokoh atau pemimpin pesantren. Hal ini dapat dilihat dari beberapa nama tokoh/pemimpin pesantren yang 
yang sudah bersentuhan dengan gagasan liberal, misalnya (alm.) KH. Abdurrahman Wahid, KH. Said Agil Siradj, KH. Masdar Farid Mas'udi. Tak ketinggalan pula, KH. Hussein Muhammad, sebagai satu-satunya ulama/kyai pesantren yang menekuni hubungan Islam dengan gender.

Kedua, dilihat dari lembaga pesantren melalui santrisantrinya yang ikut meramaikan pergulatan diskursif Islam liberal. Sebut saja, Pondok Pesantren Ma'had Ali Situbondo yang berdiri 4 Agustus 1991 yang menurut Marzuki Wahid (2004: 45-47) telah melakukan diskusi-diskusi wacana keagamaan kontemporer yang tidak lagi menampilkan wajah Islam yang tertutup dan konservatif, yang ditunjukkan dari beberapa indikator: 1) Berdirinya Fokus Kajian Ushul Fiqh pada tahun 1998. Kelompok kajian ini di samping mengkaji pemikiran ushul fiqh klasik, juga dilengkapi dengan pemikiran fiqh dan ushul fiqh yang lebih kontemporer, termasuk pemikiran Mahmoed Muhammad Thaha, Abdullahi Ahmed anNa'im, Hasan Turabi, Jamal al-Banna, dll. 2) Pusat Studi Agama dan Filsafat, yang secara serius menyelenggarakan diskusi-diskusi filsafat, baik filsafat Islam maupun filsafat Barat. Pusat Studi ini akrab dengan pemikiran para tokoh non-Muslim yang dikenal berhaluan kiri, seperti pemikiran Mao, Karl Marx, Max Weber, dll. 3) Buletin mingguan "Tanwirul Afkar" membahas masalah kontemporer dengan analisis sosial dan analisis fiqhiyyah. Kini telah menjadi sebuah buku yang berjudul "Fiqh rakyat: Pertautan Fiqh dengan kekuasaan yang diterbitkan LKiS Yogyakarta.

Narasumber atau dosen tamunya pun lebih sering menggunakan pemikir yang berani melakukan pemikiran kritis, seperti KH. Abdurrahman Wahid, KH sahal Mahfudh, KH Ali Yafie, Prof Dr. Quraish Shihab, Prof. Dr. Nurcholish Madjid. KH Masdar F. Mas'udi, KH. Said Agil Siradj, KH. A. Muhith Muzadi. Dari sinilah terjadi kontak gagasan yang beraneka ragam di antara santri dan para ustadnya yang lintas pemikiran dan mazhab. Pergulatan intelektual yang terjadi di Ma'had Ali Situbondo ini bisa dikelompokkan sebagai salah satu prototype dari pesantren liberal, meski dalam batas-batas tertentu tidak bisa dianggap sebagai pesantren liberal. Tetapi paling tidak Ma'had Ali Situbondo dianggap telah menerima pemikiran liberal yang dibawa dari luar. 


\section{Menimbang Radikalisme dan Liberalisme, Mengawal Moderatisme}

Fenomena fundamentalisme dan radikalisme pesantren sesungguhnya sesuatu yang aneh, dan baru belakangan ini terjadi. Pesantren sebagai institusi keagamaan sebenarnya tidak didirikan untuk melahirkan radialisme. Pesantren bertugas untuk mencetak kader-kader ulama yang berpengetahuan luas (Wahid, 1999:16). Karena itu, pesantren mengajarkan semua hal yang ada di dalam agama; dari tauhid, syariat, hingga akhlak. Kesemuanya ini bertujuan agar selepas dari pesantren kelak, para santri dapat melakukan dakwah agama ke tengah-tengah masyarakat secara mumpuni.

Bahkan, karakter otentik pesantren dari zaman awal berdirinya pesantren sesungguhnya menampilkan wajahnya yang toleran dan damai. Di pelosok-pelosok pedesaan Jawa, Sumatera, dan Kalimantan, banyak ditemukan performance pesantren yang berhasil melakukan dialog dengan budaya masyarakat setempat. Pesantren-pesantren yang ada di Jawa, terutama yang bermazhab Syafi'i dan memiliki hubungan dekat dengan Nahdlatul Ulama (NU) menampilkan sikap akomodasi yang seimbang dengan budaya setempat. Sehingga pesantren mengalami pembauran dengan masyarakat secara baik. Keberhasilan pesantren seperti ini kemudian menjadi model keberagamaan yang toleran di kalangan umat Islam pada umumnya. Tak heran, jika karakter Islam di Indonesia seringkali dipersepsikan sebagai Muslim yang ramah dan damai. Karena itu, hampir tidak pernah terjadi proses radikalisasi di kalangan santri atas nama doktrin agama dalam bentuk aksi kekerasan.

Namun demikian, seiring dengan beragamnya corak pesantren di wilayah Nusantara; dari yang namanya pesantren Salaf/tradisonal; pesantren yang hanya mengajarkan ilmu-ilmu agama, khususnya Islam klasik, sampai kemudian dimarakkan dengan pesantren Khalaf/ modern, yang sudah mengajarkan mata pelajaran umum, wajah pesantren perlahan-lahan berubah. Pesantren tidak lagi menjadi agen perubahan sosial dengan kemampuanya beradaptasi dengan tradisi lokal, melainkan melakukan purifikasi yang luar biasa. Bahkan dalam beberapa kasus, pesantren justru memproduksi radikalisme secara doktrinal. Inilah yang kemudian ikut mempersubur gejala radikalisme di kalangan pesantren. 
Di sinilah radikalisme pesantren harus dimaknai sebagai gugatan terhadap wajah pesantren pada umumnya yang telah mengajarkan agama tidak seperti yang diajarkan Rasulullah Saw. di masa-masa awal Islam. Gugatan demi gugatan dilakukan dengan melakukan purifikasi ajaran dan praktek keagamaan yang dianggap sinkretik secara besar-besaran. Dalam hal ini, mereka menginginkan agar semua pesantren tidak begitu saja menyesuaikan dengan tradisi lokal yang berbau bid'ah. Pada tahap selanjutnya, terjadilah radikalisme dalam wilayah doktrinal dan praktek keagamaannya.

Dalam konteks inilah, pesantren mesti melakukan introspeksi terhadap ajaran dasarnya agar tidak terlalu literal dan kaku dalam merespon perubahan zaman. Bukankah radikalisme pesantren justru menambah citra negatif masyarakat Muslim di tanah air? Dengan demikian, pesantren mesti dikembalikan ke dalam format awalnya sebagai pusat pendidikan agama yang mampu melakukan adaptasi dengan kebudayaan masyarakat setempat secara baik, tanpa harus saling menafikan. Dalam konteks selanjutnya, pesantren diharapkan dapat mencetak kader-kader muda beragama yang tidak bersikap apatis terhadap zaman, melainkan memunculkan optimisme terhadap masa depan kehidupan umat manusia yang mencerminkan toleransi dan perdamaian.

Sedangkan wacana liberalisme di kalangan pesantren memang terasa mengejutkan dan sering mengundang perdebatan. Apalagi, liberalisme jika dikaitkan dengan masalah agama, maka asumsi pertama yang muncul adalah menggugat kembali ide tersebut. Begitu pula ketika liberalisme dihubungkan dengan pesantren sebagai institusi sosial keagamaan, secara sadar akan melahirkan gugatan yang sama.

Gugatan yang berkaitan dengan wajah Islam yang dibawa pesantren ini muncul karena lembaga pendidikan tertua ini meniscayakan kepatuhan secara mutlak, kepasrahan, dan pengabdian, transendensi, dan pembatasan-pembatasan keilmuan yang diajarkan oleh kyai (Bruinessen, 1994: 135). Sementara liberalisme terkait dengan filsafat dekonstruktif yang menisbikan kemutlakan, mendambakan kebebasan, dan anti transendensi (Binder, 1988: 4-5). 
Hanief (2002: 19) mengungkapkan tentang beberapa karakteristik yang menandai lahirnya Islam liberal. Pertama, ingin melepaskan diri dari tradisi. Mereka datang dari tradisi, tetapi tradisi ini hanya dijadikan sebagai pijakan untuk melaksanakan tranformasi. Tradisi tidak diterima apa adanya atau ditentang mentah-mentah, melainkan diusung secara kreatif untuk melahirkan khazanah baru. Tradisi ini menyangkut tradisi keagamaan berikut tradisi keilmuan. Kedua, melepaskan beban sejarah umat Islam, dari sektarian-primordial menjadi pluralis universal. Tujuannya adalah mengkategorisasikan umat Islam sebagai bagian sejarah kemanusian universal yang berkeadilan dan demokratik yang tidak terbatas pada keinginan hegemonik politik dan menindas kelompok lain. Ketiga, menghindarkan diri dari pemaknaan harfiah teks-teks keagamaan yang dilakukan oleh para ulama pertengahan.

Pesantren di sini berfungsi sebagai entitas yang paling siap memanfaatkan tradisi sebagai bagian bangunan pembaruan khazanah kehidupan baru, tidak terkecuali seperti yang dilaksanakan oleh kelompok Islam liberal. Bahkan, KH Husein Muhammad menengarai akar-akar liberalisme sudah mulai tumbuh di lingkungan pesantren. Hanya saja, epistimologinya yang belum mereka kuasai. Pesantren mengajarkan pemikiran-pemikiran pluralistik, sehingga mereka cenderung menghargai keberagaman pemikiran, bersikap terbuka dan kritis. Hal ini dapat dilihat semakin intensifnya halaqah dan pelatihan di pesantren-pesantren mengenai tema-tema demokrasi, pluralisme, keadilan, kesetaraan gender, dan HAM. Tidak hanya itu, metodologi pemikiran yang dikatakan modern, seperti rasionalisme dan empirisme, juga telah menjadi kecenderungan baru para santri.

Adapun sikap moderatisme tidaklah menjadikan pesantren kaku dalam menghadapi fenomena globalisasi, namun juga tidak menerima seluruhnya tanpa adanya reserve. Lembaga pesantren akan menerima globalisasi apabila ia menimbulkan kemaslahatan bagi manusia. Pada disi lain, pesantren akan menolak globalisasi jika ia memberikan kerusakan bagi peradaban manusia dan tidak selaras dengan nilai-nilai Islam. Ringkasnya pesantren akan mengantisipasi dan mengkritisi globalisasi dari segi konten, bukan dalam bentuk media/alat globalisasi seperti teknologi informasi, komunikasi dan transportasi. 
Mengikuti pendapat Mahmud Hamdi Zaqzuq (2004: 4), idealnya umat Islam-termasuk masyarakat pesantren-tidak mengambil posisi sebagai pendukung atau penentang globalisasi. Namun, harus menyikapi globalisasi secara kritis dengan menelaah setiap permasalahan yang berkembang dari segala sisinya, bukan justru tergesa-gesa ikut mendukung atau sebaliknya menolak arus baru yang datang tanpa disertai kesadaran yang utuh.

\section{Simpulan}

Sejalan dengan globalisasi, wajah pesantren di Indonesia sudah tidak lagi dimonopoli oleh kelompok Islam tradisional atau fundamental-radikal, melainkan sudah diwarnai oleh pesantrenpesantren baru yang dibentuk oleh kelompok Islam lainnya dengan wajah pesantren yang berbeda pula. Dari visi, tujuan, pola pendidikan, serta literatur yang digunakan, tampak bahwa pesantren yang berwajah radikal berkiblat kepada model Islam Timur Tengah. Sementara pesantren lama yang mendirikan lembaga baru di lingkungan pesantren, seperti kasus Ma'had Ali Situbondo menampilkan wajah pesantren yang akomodatif terhadap perubahan dan gagasan-gagasan baru.

Dengan demikian, radikalisme dan liberalisme sebuah pesantren sangat tergantung para pemimpin pesantren tersebut (pemilik, kyai, atau santri senior). Jika arus pemikiran para pemimpinnya berkarakter radikal, maka pesantren dan isinya memiliki kecenderungan berpandanagan radikal, sedangkan jika para pemimpinnya berkarakter moderat, maka sebuah pesantren beserta santrinya berkarakter moderat, bahkan bisa menjadi liberal dalam situasi dan waktu tertentu. 


\section{DAFTAR PUSTAKA}

Azizy, Qodry. 2004. Melawan Globalisasi: Reinterpretasi Ajaran Islam. Yogyakarta: Pustaka Pelajar.

Baso, Ahmad. 2001. "Neomodernisme Islam versus PostTradisionalisme Islam”, dalam Jurnal tashwirul Afkar Edisi No. 10.

Binder, Leonard. 1988. Islamic Liberalism: A Critique of Development Ideologies. Oxford: Oxford University.

Bruinessen, Martin Van. 1994. NU: Tradisi, Relasi-relasi Kuasa dan Pencarian Wacana Baru, Yogyakarta: LKIS.

Dirjosanjoto, Pradjarta1. 999. Memelihara Ummat. Kiai Pesantren-Kiai Langgar di Jawa, Yogyakarta: LKiS.

Effendy, Bisri. 1991. Transformasi Ummat di Tengah Ajaran Agama Baku, Prisma, Jakarta: LP3ES, No.3, Thn. XX.

Muhtarom. 2005. Reproduksi Ulama di Era Globalisasi: Resistensi Tradisional Islam. Yogyakarta: Pustaka Pelajar.

Muin, Abd. 2007. Pendidikan Pesantren dan Potensi Radikalisme, Jakarta: Prasasti.

Rumadi. 2000. "Menebar Wacana, Menyodok Tradisi: Geliat Mencari Makna Liberalisme”, dalam Jurnal Tashwirul Afkar, Edisi No. 9.

Turmudi, Endang \& Sihbudi, Riza (ed.). 2005. Islam dan Radikalisme di Indonesia, Jakarta: LIPI Press.

Wahid, Marzuki. dkk (ed.). 1999. Pesantren Masa Depan, Bandung: Pustaka Hidayah.

Zada, Khamami. 2002. Islam Radikal: Pergulatan Ormas-ormas Radikal di Indonesia, Jakarta: Teraju.

Zaqzuq, Mahmud Hamdi. 2004. Reposisi Islam di Era Globalisasi, Yogyakarta: LkiS. 
halaman ini bukan sengaja dikosongkan 